\title{
Tourists' vision about the implementation of sustainable development practices in the hospitality industry in Romania
}

\author{
Anca MADAR \\ Transilvania University of Brasov, Brasov, Romania \\ ancamadar@unitbv.ro \\ Nicoleta Andreea NEACȘU \\ Transilvania University of Brasov, Brasov, Romania \\ deea.neacsu@yahoo.com
}

\begin{abstract}
It has been shown that the development of tourism brings many benefits to the areas where this activity takes place (jobs, incomes for the community and for individuals, etc.), but it also has some shortcomings, such as the environmental degradation and the negative impact on local traditions. In order to stop these negative effects, the concept of sustainable development must be applied. This paper wants to identify the extent to which tourists are familiar with the term of ,,sustainability" and how they perceive the implementation of sustainable practices in the tourism sector in Romania. The research also wanted to reveal whether the application of sustainable development practices in this sector influenced tourists in choosing a specific economic agent. The authors have conducted a qualitative marketing research,and interviewed tourists who have used tourist services in Romania for the last 5 years. The research was based on the semi-structured depth interview method. The results show that most of the interviewees do not have a very clear idea about the concept of , sustainability" and that of the implementation of consistent practices in the hospitality industry. Therefore, they do not consider the application of these practices when choosing a certain economic agent for spending their free time. The results of this research can be the basis of some governmental and nongovernmental programs for educating potential tourists regarding the impact of tourism on the environment and the need for sustainable development of this sector. Also, these results can be useful to the economic operators in the tourism industry, to consider participating in the sustainable development of the sector and to take measures to promote the sustainable practices that they have applied.
\end{abstract}

Keywords: tourist, hospitality industriy, sustainable development, economic agents, qualitative research, education programms

\section{Introduction}

This paper wants to highlight the perception of tourists who have chosen the tourist services in Romania, regarding the application of sustainable development practices in this industry. In a previous paper, the authors approached this topic from the perspective of the managers of the mountain tourism units in Romania and, decided to conduct further reseach to understand what tourists think about this aspect.

For a better understanding of the purpose and objectives of this paper, the theoretical framework of sustainable development, as described in the specialized literature, was first addressed, then the legislative Romanian framework of sustainable tourism and the goverment's strategy in this direction.

In order to highlight the tourists' vision on the implementation of sustainable practices in the tourism sector in Romania, a qualitative research has been conducted, based on the semistructured depth interview method. 
The results of the research show that most of the interviewees do not know very well the term of ,sustainable development”, but agree that Romanian tourism needs such a development. They argue that, when choosing a specific economic for leisure, they do not take this aspect into account.

The conclusions of this paper shows that although some economic operators operating in the field of tourism have to some extent implemented some of the practices of sustainable development, they have not been promoted to tourists so they do not notice them. Also, the authors make some proposals to improve this aspect.

\section{Literature review}

Tourism is one of the fastest growing industries in the world and is a major source of income for many countries. As Blasco López et al (2018) points out, this sector rewards economic, social and market benefits by increasing incomes and employment opportunities, encouraging rural business activities, improving infrastructure, preserving community culture and enhancing cultural exchanges.

The data published by UNWTO in September 2019 shows a 4\% increase in the international tourist arrivals indicator (overnight stays), from January to June 2019 compared to the same period of the previous year. The highest growth was in the Middle East (+ $8 \%$ ), followed by Asia and the Pacific $(+6 \%)$, Europe $(+4 \%)$, Africa $(+3 \%)$ and the Americas $(+$ $2 \%)$. By regions, the Caribbean increased by $+11 \%$, followed by North Africa $(+9)$, South Asia and North East by $+7 \%$ (UNWTO, 2019).

Being a people-oriented industry, tourism also offers numerous jobs that have helped revitalize local economies.

Stone G.W. (2019) specifies that the term overtourism refers to an excessive number of tourist visits to a popular destination or attraction, which can lead to deterioration of the environment and local historical sites and poorer life quality for the residents. Pan et al., (2018) also spoke about the negative effects of tourism activity on the economy, environment, society and culture, in the paper called "Advances and challenges in sustainable tourism towards a green economy". These effects have also been covered by Wearing, Stevenson, \& Young, (2010), in the paper "Tourist cultures: Identity, place and the traveler". As the consequences of excessive tourism are visible all over the world, WTO has declared September 27 as World Tourism Day and uses this platform to discuss the social, political, economic and environmental impact of tourism.

In order to counteract the harmful effects of this phenomenon, it is necessary to implement a sustainable tourism management, which will affect to a lesser extent the tourist destinations and their permanent inhabitants and, to keep the natural resources in a state as unaltered as long as possible (Almeida et al., 2019; Harazneh et al., 2018; Zamfir \& Corbos, 2015). This idea is also found in Stone G. W., which lists among the objectives of sustainable tourism the protection of the environment, the approach of climate change, the minimization of plastic consumption and the expansion of economic development in the communities affected by tourism. Marinescu \& Burcea (2012) state that sustainable consumption behavior is the key element of long-term development. In this regard, the incorporation of sustainability policies into the strategic planning of tourist activities and entities has become increasingly necessary (Estêvão et al, 2019).

The United Nations' Brundtland Commission defined sustainable development as "development that meets the needs of the present without compromising the ability of future 
generations to meet their own needs" (Asmar, 2009). It aims to provide people with an interesting and educational vacation, which will also be beneficial to the people of the host country. According to Kunasekaran et al (2017), although there is not enough specific theory to address sustainable domestic tourism, a green paradigm has been the backbone of studies on this topic. This paradigm emphasizes that people are part of nature.

Sustainable tourism is a process that involves maximizing benefits and minimizing costs while satisfying tourists and involving the community in tourism decisions (Cottrell, S. P., Vaske, J. J., \& Roemer, J. F., 2013).

In the specialty literature, there has not been much research that reflects tourists knowledge of sustainability, their interest in sustainable tourism and the link between sustainable practices implemented in tourism units and their impact on tourists' choice of tourism units. Other studies looked at residents 'perception of corporate social responsibility initiatives of hotels (Gursoya et al, 2019), the structural relationship between tourist satisfaction and sustainable tourism development. (Atsbha, Gebreegziabher Asmelash, Satinder Kumar, 2019), residents' attitude as a determinant of the sustainability of tourism (Blasco López, 2018).

The European Commission recognises its responsibilities for action and will implement initiatives at European level regarding sustainable tourism. The "Agenda for a sustainable and competitive European tourism" fulfills, a long-term commitment made by the European Commission and further supported by the other European institutions. Reaching the objectives of this agenda will require a coherent action that can be supported by appropriate public policies: sustainable management of destinations, integration of sustainability concerns by businesses and awareness of sustainability by tourists. This agenda will guide the Commission's future activities in the field of tourism and in all other policy areas that have an impact on tourism and its sustainability. To this end, the Commission will rely on the Tourism Sustainability Group (https://eur-lex.europa.eu/legal-content).

To underline the increasing importance of implementing sustainable tourism with the development of new technologies, the 18th European Tourism Forum (2019) had the title "Digital transformation as the engine of sustainable growth for the EU tourism sector".

There are several projects at EU level that support responsible and sustainable tourism growth. One of them focuses on developing certificates and tools to help destinations monitor sustainability performance. For example, accommodation units that use mechanisms to reduce the impact on the environment, display eco-certificates and eco-labels.

At the same time, the EU helps tourism businesses, especially the small and mediumsized ones, to have access to funds to adapt more easily to new technologies. Through a program implemented in 2014, valid until 2020, entrepreneurs from all EU countries have access to a \$ 5 billion fund, which helps them turn their businesses into responsible and sustainable ones. One of the most important projects is the investment in the professional training of the tourism workforce. Training programs teach people to develop the skills they need in a sector that wants to become sustainable, here we talk about "green" and digital "skills."(ttps://www.wallstreet.ro/articol/Turism).

In Romania, the tourism activity is carried out in accordance with the Tourism Law. In Chapter I, Article 2 defines sustainable tourism as follows: development of all forms of tourism, tourism management and marketing that respects the natural, social and economic integrity of the environment and which ensures the exploitation of natural and cultural resources for future generations. Also, the law stipulates that the state supports the tourism activity through policies, 
economic-financial mechanisms and actions for capitalizing and protecting the tourist heritage (Tourism Law, 2019).

The concerns for the sustainable development were materialized in the adoption by the Government of Romania in the meeting of November 9, 2018, by GD no. 877/2018 of the National Strategy for the Sustainable Development of Romania 2030. Tourism was included in this strategy as an important branch of the economy. In this document it is specified that Romania ratified the Protocol on sustainable tourism at the Framework Convention on the Protection and Sustainable Development of the Carpathians and inaugurated the National Center within the Carpathian Platform for Sustainable Tourism. It is also specified that the Master Plan for the Development of the National Tourism of Romania 2007-2026 is under implementation. This plan considers:

- optimal use of environmental resources, which is a key element in the development of tourism, maintaining essential ecological processes and contributing to the conservation of natural heritage and biodiversity;

- respecting the socio-cultural authenticity of the host communities, preserving the built heritage, cultural life and traditional values contributing to the intercultural understanding and tolerance;

- ensuring long-term viable economic operations that provide socio-economic benefits for all stakeholders, being properly distributed, including stable jobs and opportunities to earn income and social services for communities contributing to poverty reduction (Ministry of Education and Research, 2019).

The general objective of the Convention, which brings together the Czech Republic, Poland, Serbia, the Slovak Republic, Ukraine, Hungary and Romania, is the cooperation for the preservation and sustainable development of the Carpathians in order to improve the life quality of the local populations and to preserve the natural and cultural values. Accession to the Convention has created the general framework for cooperation in various fields such as: biodiversity conservation, spatial planning, water resource management, agriculture and forestry, transport, tourism, industry and energy. The Convention benefits from assistance from the United Nations Environment Program (UNEP), which established in 2004 an interim Secretariat of the Vienna Convention, coordinated by the UNEP Regional Office for Europe (CNPCTD, 2019).

Although the legislative framework exists and the authorities have assumed responsibility for supporting tourism for the implementation of sustainable development practices, (Brătucu G. et al, 2017), the managers of the hospitality industry in Romania are accuseing the insufficient support from the authorities both financially and legally, as well as the consultations for accessing funds in this regard.

At the same time, a number of non-governmental associations operating in Romania also work to educate citizens and especially the younger generation for sustainable development. The Association of the Center for Education for Sustainable Development aims to promote education in urban and rural communities in order to raise awareness of the problems generated by human activities on the components of the natural environment and to improve the quality of life conditions. The Center for Mountain Ecology is a non-profit ecological foundation specialized in the protection of mountain and alpine ecology. The Green Tourism Association militates for Romania to become a sustainable (green) tourism destination in the future, with a cohesive territory, an innovative and competitive country, which will enhance the richness of the natural environment, an open, creative country in which to visit and to visit have a good time. 
Tourists also play an important role in the development of sustainable tourism. In order to be able to participate actively in this development, they need to be aware of the impact of tourism on local communities and the environment, on the measures that can be implemented by the tourism agents and on the contribution they can bring. This involves programs to educate potential tourists and raise their awareness in choosing those economic agents that implement sustainable development practices.

PICBE | 773

Education for sustainable development is also addressed in the formal curriculum of preuniversity education in Romania, but also in extracurricular activities (especially within the national program Școala Altfel). Education for Sustainable Development is carried out noninformally and informally and through the numerous partnerships that the Ministry of National Education has with central and local public authorities, economic operators and NGOs. With regard to higher education, universities have begun to introduce elements of sustainable development, new disciplines in the compulsory or optional curriculum, depending on the study programs (https://www.edu.ro).

\section{Methodology}

In order to quantify the extent to which tourists visiting Romania know the term ,sustainable development" and to estimate their perception in relation to the application of sustainable development practices in this sector, the authors conducted a qualitative marketing research, based on the semi-directional interview method. Thus, 32 tourists were interviewed who resorted to the tourist services in Romania.

The main objective of the research to understand the perception of the tourists who used tourist services in Romania, regarding the application of sustainable development practices in this industry. The specific objectives pursued through research were:

- to determine the extent to which tourists know the concept of ,sustainable development”;

- to determine the opinions of the tourists the necessity of implementing sustainable development practices by the economic agents in the hospitality industry;

- to determine the extent to which tourists know what sustainable development measures have been implemented by the economic agents in the hospitality industry in Romania;

- to determine the extent to which the application of sustainable development practices in Romanian tourism influence tourists when choosing a certain economic agent.

The qualitative research method chosen was the interview, and the qualitative research technique was the in-depth interview (Bratucu et al., 2017). As therese techinques were considered appropriate by the authors who wished to know the opinions of tourists who chose to the tourist services in Romania. The procedure used in the research was the semi-structured interview, using the interview guideas an instrument. The sample consisted of 32 people, of which 28 Romanian and 4 foreign tourists. Participation in the interview was done on a voluntary basis, using a selection questionnaire prior to the beginning of which the purpose and objectives of the research were presented. After receiving the acceptance from the 32 tourists, the guide for the in-depth interview was implemented.

As this is a qualitative research, the sample is not representative, and its composition is presented in table no. 1.

\begin{tabular}{|l|l|l|l|l|l|l|l|}
\hline \multirow{2}{*}{ Criterion } & Sex & Age & \multicolumn{3}{l|}{ origine } \\
\cline { 2 - 8 } & Male & Female & $<\mathbf{3 0}$ & $\mathbf{3 0 - 5 0}$ & $<\mathbf{5 0}$ & Romanian & foreign \\
\hline & 12 & 20 & 8 & 14 & 10 & 28 & 4 \\
\hline
\end{tabular}




\begin{tabular}{|l|l|l|l|}
\hline Total & 32 & 32 & 32 \\
\hline \multicolumn{3}{|c|}{ Source: Authors' own research }
\end{tabular}

The in-depth interview was conducted between May and June 2019 and was based on specific topics. The results were recorded and stored electronically and then transcribed and analyzed using a technique called content analysis (Bratucu et al., 2017).

PICBE | 774

\section{Results and discussions}

After transcription and centralization, the interviews were analyzed under two aspects (Cătoiu, 2002):

- the vertical analysis, through the individual approach of each interview, respectively the opinions of each tourist, situation in which was highlighted the attention paid by them to the problems included in the sub-sections of the in-depth interview;

- the horizontal analysis, through the synthesis of the approach of each subject to analysis by all 32 tourists.

- Theme no. 1. Tourists' understanding aboutsustainable development in society

- Theme no. 2. The need to implement sustainable development practices in tourism

-Theme no. 3. Known sustainable development practices implemented in Romanian tourism

- Theme no. 4. The influence of the implementation of sustainable development practices

in the tourism sector, in the selection of economic agents by tourists

- Theme no. 1.sustainable development in society

Of the interviewees, 30 subjects $(93.75 \%)$ stated that they know the concept of sustainable development and only for two subjects this term was new/ unknown. They said they would be interested in learning more about it and will look into deepening their knowledge abut it.

The interviewees were asked to explain what the term "sustainable development" means to them. Those who have stated that the term is known have defined it, in one form or another, as an activity that uses natural resources and is currently in progress, respectively, satisfying the needs of the current generation, without exhausting the resources used, thus ensuring it the same resources and the wellbeing of future generations.

Regarding the need for sustainable development, 28 people responded that it is necessary the field of these activities, while the other 4 people were uncertain and confused about the need to implementing sustainable development measures.

The reasons why $87.5 \%$ of those surveyed believe that the implementation of the principles of sustainable development in society are important, are: to help conserve existing resources, mitigate the effects of pollution, find alternatives to aggressive activities with the environment and ensure the prosperity of the society in the future.

Six of the respondents discussed, reaeal any human activity should be based on long-term thinking and development actions that do not adversely affect the environment. Most of the respondents were concerned that the actions of implementing sustainable development practices are very few.

All the foreign respondents who participated in the interview were aware of the concept of sustainability, considered that the sustainable development in a society was necessary and they were interested to participate actively in actions that would help a sustainable development of the society. Of the 28 Romanian respondents who participated in the interview, the majority (24), $85,71 \%$, considered the sustainable development in a society necessary, but when asked if they 
would actively participate in actions that would help a sustainable development of the society only $14(58,33 \%)$ of them they were interested, the other 10 people being circumspect and interested only if these actions would not involve too much cost and effort.

- Theme no. 2. The need to implement sustainable development practices in tourism

The second interview theme sought to find out what is the view of the respondents regarding the need to implement sustainable development practices in the hospitality industry.

Regarding the implementation of sustainable development practices in the tourism activity, 30 people agreed that they are absolutely necessary. Only two people were neutral, saying that these practices depend on the location of the tourist unit.

Among the various fields that exist in the hospitality industry, the respondents mentioned that sustainable development practices must first be implemented in the accommodation activity and secondly in the public food.

Several reasons were raised about the need for the implementation of sustainable development practices. 14 respondents $(46.7 \%)$ stated that the protection and conservation of the environment are important (especially to reduce pollution), 10 respondents $(33.3 \%)$ considered them necessary to create a balance between the natural and the anthropic environment, and 6 respondents $(20 \%)$ stated that these are important so that for the future genteration can enjoy tourism.

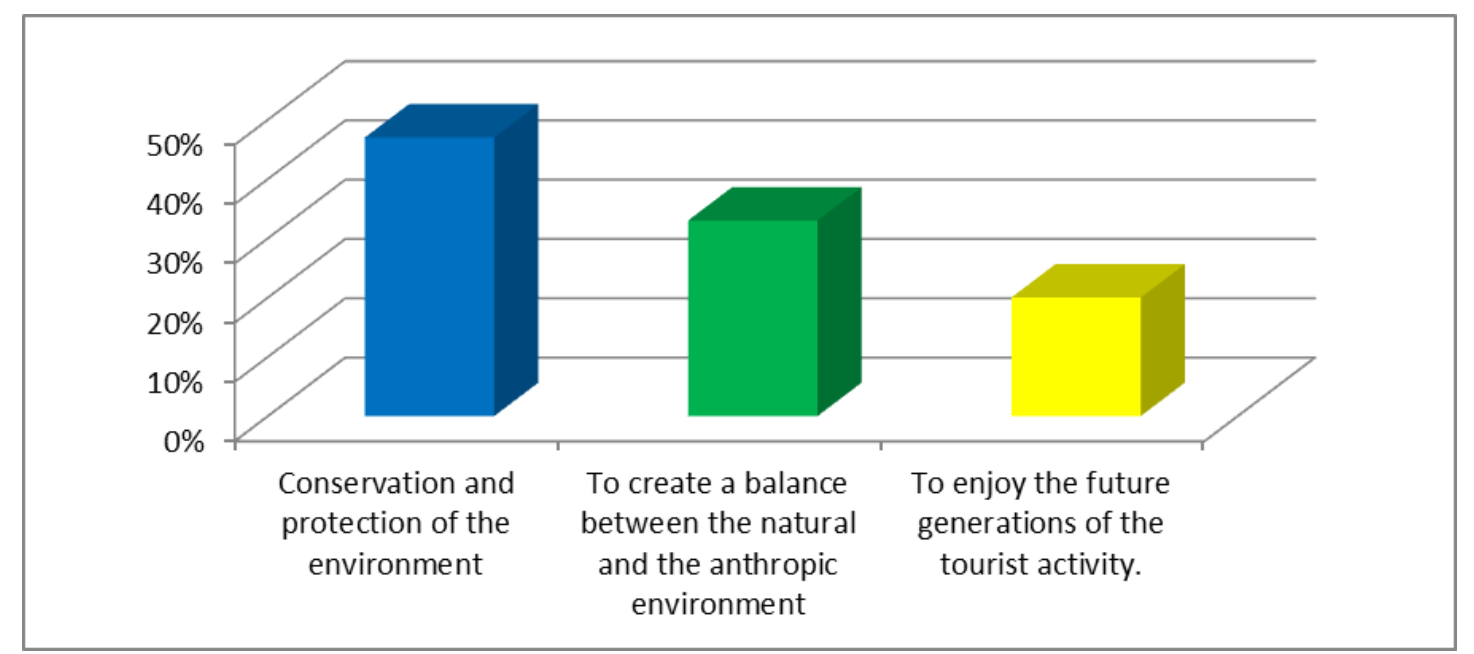

Figure 1.The motivation of the need to implement sustainable development practices

Source: Authors' own research

The most popular sustainable development practices that tourists consider necessary to implement in the tourism sector are: the use of renewable energy sources, the use of environmentally friendly cosmetics and educating tourists to turn off the heat and electricity when they leave the room.

- Theme no. 3. Known sustainable development practices implemented in Romanian tourism

The third theme of the interview aimed to discover what sustainable development practices tourists encountered in the tourism sector in Romania.

Sustainable development practices most commonly encountered by respondents in the Romanian tourism sector (in locations) that they visited are: the presence of solar panels (10 persons, respectively $31.25 \%$ ), the presence of gardens and orchards traditionally maintained (8 
persons, respectively $25 \%$ ) that offers organic products for tourists, selective waste collection system (6 persons, $18.75 \%$ respectively), methods of saving water and energy (4 persons, respectively $12.5 \%)$.

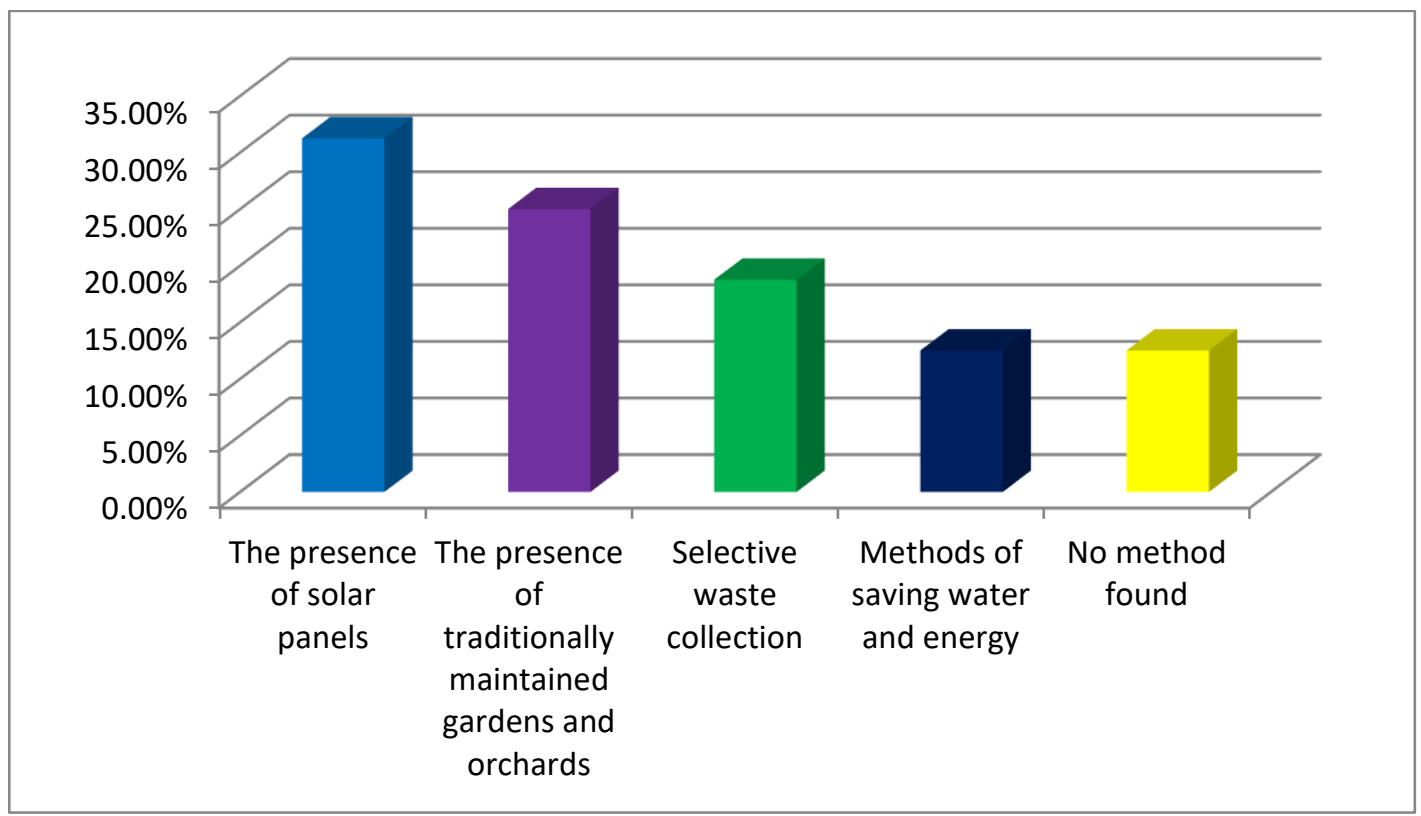

PICBE | 776

Figure 2. The most common practices of sustainable development in the tourism sector in Romania

Source: Authors' own research

Of the respondents, $12.5 \%$ (respectively 4 persons) do not know and do not remember having met any measure of sustainable development in the tourist locations they visited in Romania.

All respondents would like to meet more sustainable development practices and as best implemented, thus proving a high degree of interest for environmental protection and conservation of existing resources. They also considers it important to have information on the practices implemented in the descriptions of the tourist units. Thus, these practices, the subjects agreed, will become important features in choosing an accommodation or a food unit for each tourist aware of the effects of pollution and global warming. The subjects believe that the implementation of sustainable development actions would contribute to: improving the image of the company and would offer marketing advantages to the respective locations.

It should be mentioned that the sustainable practices encountered by tourists are applied sporadic by the economic agents in this sector and, not for the purpose of protecting the environment and for sustainable activity, but for their own economic or marketing advantages. This aspect is supported by the fact that no respondent stated that he had encountered any environmentally certified tourist unit.

- Theme no. 4. The influence of the implementation of sustainable development practices in the tourism sector, in the selection of economic agents by tourists

The last topic of the in-depth interview sought to obtain data on how the application of sustainable development practices in the tourism sector influences the respondents in selecting the holiday location. 
Of the 32 respondents, 6 people $(20 \%)$ take into account the presence of sustainable development measures when choosing the tourist unit they will visit, out of these $4 \quad(66,67 \%)$ being tourists from abroad. The other 26 do not take these practices into account when choosing a tourist unit. The main reasons for which only so few people take into account these practices are: lack of information about the presence of such practices in promoting tourism units and poor education of Romanian tourists on sustainable development practices.

PICBE | 777

Asked what reasons they choose for their vacation location, a small part of the respondents $(18.75 \%)$ stated that they take into account the degree of comfort offered, if using organic cosmetics and allergenic pillows, if the accommodation units use organic food for the preparation meals (especially in rural tourism) and then consider the price of the produc. However, most subjects $(81.25 \%)$ responded that, first and foremost, they consider the tariff, and at close prices, they choose the ecological, sustainable variant.

The interviewed subjects drew attention to the lack of programs, at national and local level, for tourists to be aware of the potential harmful effects of tourism on the environment and to be educated on the sustainable development practices that can be implemented in tourism activities and the benefits of these practices on the environment and on society as a whole.

The respondents agreed that the number of tourist units that implement such practices is very small, some of the subjects claiming that this concept is only in theory in Romania, because they did not encounter any measures to ensure a sustainable activity in any unit visited in Romania.

One of the respondents made a comparison between the units he visited in Romania and what he saw in Switzerland. There, these measures are not something out of the ordinary, they are common practices in any tourist unit, especially due to legal regulations that oblige the implementation of these practices. The subject stated that in his opinion this is the solution also in Romania, imposing these sustainable development measures through the legislative framework for any kind of tourist unit and tourist activity.

\section{Conclusion}

The tourism sector is an important driver of the national economy (Blasco López et al, 2018). As mentioned above, the unattended development of this activity leads to overtourism, with obvious negative effects on the environment, local communities, and tourists satisfaction . Implementing sustainable development practices is an effective solution to counteract these negative effects. In order for these practices to be implemented correctly, by all the participants in the tourist activity, they must first be regulated, by the central and local authorities, and then made known both to the economic agents and to the tourists.

The implementation of sustainable development practices in the Romanian tourism is sporadic among the economic agents, for reasons that were set out by the authors in a previous article (Bratucu, G. Et al, 2017). In this paper the authors interviewed a number of tourists who spent their holidays in Romania, in relation to what they know about sustainability, if they encountered such practices in Romanian tourism and if their implementation influences them in choosing a certain economic agent. The results of the qualitative research show that some of the respondents are not aware of sustainable development practices that can be applied in tourism, and that they have not encountered such practices where they spent their vacations. On the other hand, they are interested in finding out more about this subject and support the popularization of such measures and the economic agents that implement them. However, the vast majority do not 
choose the places for spending their free time according to the criteria of implementing sustainable development practices if they contribute to the increase of the tariff.

In conclusion, based on the results from the paper, the authors recommend to the central and local authorities to invest more in presenting sustainable development practices applicable in tourism both to the economic agents working in the field, but also to tourists, through consultancy activities and educational programs. Also, the economic agents can use their own measures to promote the sustainable practices already implemented, in the programs of promotion of their own units.

Although the research carried out in this paper has the limit of the interviewed sample, which makes its results not extrapolated to the entire researched population, the authors consider that the paper has academic contributions in completing studies regarding tourists' perception of sustainable tourism and the practices implemented for this purpose and this should be the starting point for future research on this topic.

\section{References}

Almeida, F., Almeida, J. \& Mota, M. (2019). Perceptions and trends of booking online payments in tourism. Journal of Tourism and Services, 10(18), 1-15.

Asmar, S. (2009). Culture of Sustainability: Measuring Sustainable Lifestyles at the College Level (Environmental Ethics Fellowship Paper); Santa Clara University: Santa Clara, CA, USA.

Atsbha, Gebreegziabher Asmelash \& Satinder Kumar. (2019). The structural relationship between tourist satisfaction and sustainable heritage tourism development in Tigrai, Ethiopia, Heliyon 5 e01335. doi: 10.1016/j.heliyon. e01335.

Blasco López, M. F., Recuero Virto, N., Manzano, J. A. \& Miranda, J. G.-M. (2018). Residents' attitude as determinant of tourism sustainability: The case of Trujillo. Journal of Hospitality and Tourism Management, 35, 36-45.

Bratucu, G., Baltescu, C. A., Neacsu, N. A., Boscor, D., Tierean O. M. \& Madar, A. (2017). Approaching the Sustainable Development Practices in Mountain Tourism in the Romanian Carpathians. Sustainability, 9, 2051; doi:10.3390/su9112051.

Cătoiu, I., Bălan, C., Orzan, Gh., Vegheș, C., Dănețiu, T. \& Vrânceanu, D.M. (2002). Cercetări de marketing. București: Uranus.

Chen, J. S., \& Chen, Y.-L. (2016). Tourism stakeholders perceptions of service gaps in Arctic destinations: Lessons from Norway's Finnmark region. Journal of Outdoor Recreation and Tourism, 16, 1-6.

Centrul Naţional în cadrul Platformei Carpatice pentru Turism Durabil (CNPCTD). Retrieved from http://turism.gov.ro/web/2017/05/10/centrul-national-in-cadrul-platformei-carpaticepentru-turism-durabil/

Comisia Europeana. Sustenabilitatea in turism trebuie sa devina o prioritate. Ce face Europa pentru dezvoltarea turismului responsabil? Retrieved from ttps://www.wallstreet.ro/articol/Turism/239952/comisia-europeana-sustenabilitatea-in-turism-trebuie-sadevina-o-prioritate-ce-face-europa-pentru-dezvoltarea-turismului-respons.html\#gref)

Communication from the Commission. Agenda for a sustainable and competitive European tourism. Retrieved from https://eur-lex.europa.eu/legalcontent/EN/TXT/?uri=CELEX:52007DC0621.

Cottrell, S. P., Vaske, J. J., \& Roemer, J. F. (2013). Resident satisfaction with sustainable tourism: The case of Frankenwald Nature Park, Germany. Tourism Management 
Perspectives, 8, 42-48.

Educație pentru Dezvoltare Durabilă. Retrieved from https://www.edu.ro/educa\%C8\%9Biepentru-dezvoltare-durabil $\% \mathrm{C} 4 \% 83$

Estêvão, Rita S.G., Ferreira, Fernando A.F., Rosa, Álvaro A., Govindan, K. \& MeidutėKavaliauskienè, I. (2019). A socio-technical approach to the assessment of sustainable tourism: Adding value with a comprehensive process-oriented framework. Journal of PICBE | 779 Cleaner Production, 236, 117487.

Harazaneh, I., Al-Tall, R.M., Al-Zyoud, M.F., \& Abubakar, A.M. (2018). Motivational factors for educational tourism: marketing insights. Management \& Marketing. Challenges for the Knowledge Society, 13(1), 796-811.

Kunasekaran, P., Gill, S. S., Ramachandran, S., Shuib, A., Baum, T. \& Afandi S. H. M. (2017). Measuring Sustainable Indigenous Tourism Indicators: A Case of Mah Meri Ethnic Group in Carey Island, Malaysia. Sustainability, 9, 1256; doi:10.3390/su9071256.

Legea turismului. Retrieved from http://turism.gov.ro/web/wp-content/uploads/2019/04/Legeaturismului-.pdf

Gursoy, D., Boğan, E., Dedeoğlu, B. B. \& Çalışkan C. (2019). Residents' perceptions of hotels' corporate social responsibility initiatives and its impact on residents' sentiments to community and support for additional tourism development. Journal of Hospitality and Tourism Management, 39, 117-128.

Marinescu, P. \& Burcea, M. (2012). Information and Ecological Behaviour towards the Natural Resources Consumption of the Population of Bucharest. Amfiteatru Economic, XIV, 142156.

Ministerul Educatiei şi Cercetării. Strategia naţională pentru dezvoltarea durabilă a României 2030. Retrived from https://www.edu.ro/sites/default/files/Strategia-nationala-pentrudezvoltarea-durabila-a-Rom\%C3\%A2niei-2030.pdf.

Pan, S.-Y., Gao, M., Kim, H., Shah, K. J., Pei, S.-L., \& Chiang, P.-C. (2018). Advances and challenges in sustainable tourism toward a green economy. Science of the Total Environment, 635, 452-469.

Stone, G. W. For travelers, sustainability is the word-but there are many definitions of it. Retrieved from https://www.nationalgeographic.com/travel/features/what-sustainabletourism-means/.

UNWTO. World Tourism Barometer and Statistical Annex, September 2019. Retrived from https://www.e-unwto.org/doi/pdf/10.18111/wtobarometereng.2019.17.1.3

Wearing, S. L., Stevenson, D., \& Young, T. (2010). Tourist cultures: Identity, place and the traveller. Thousand Oaks: SAGE.

Zamfir, A. \& Corbos, R.A. (2015). Towards sustainable tourism development in urban areas: Case study on Bucharest as tourist destination. Sustainability ,7, 12709-12722. 